\title{
DEMOGRAPHIC, LABORATORY AND IMMUNOLOGICAL PROFILE OF HIV SEROPOSITIVE CRYPTOCOCCAL MENINGITIS
}

\author{
Madhusudhan N. S1
}

\section{HOW TO CITE THIS ARTICLE:}

Madhusudhan N.S. "Demographic, Laboratory and Immunological Profile of HIV Seropositive Cryptococcal Meningitis". Journal of Evolution of Medical and Dental Sciences 2014; Vol. 3, Issue 11, March 17;

Page: 2720-2726, DOI: $10.14260 /$ jemds/2014/2199

ABSTRACT: BACKGROUND AND OBJECTIVES: Cryptococcal meningitis is an important cause of mortality among HIV infected patients. A prospective study consisting of 106 HIV seropositive patients was undertaken to know the incidence of Cryptococcal meningitis, to correlate with CD4 count, to analyze the distribution of demographic factors like age, sex and symptoms and biochemical and cytological changes in cerebrospinal fluid. METHODS: CSF samples from HIV seropositive patients with suspected meningitis were subjected to Cytological and biochemical analysis. Latex agglutination test for antigen detection (LAT). CD4 cell count estimated by Flow cytometry. RESULTS: LAT was positive in $29(27.36 \%)$ patients. The incidence was highest (38.7\%) in patients with CD4 count $<51$ cells/ $\mu$ l. With CD4 count range 51-400 cells/ $\mu$, the incidence was $22.6 \%$. CONCLUSION: The incidence of Cryptococcal meningitis was 27.36\%. Males and females were equally susceptible to cryptococcal meningitis. Majority (75.85\%) revealed severe depletion of CD4 count $(<100)$. Cryptococcal meningitis patients presented with symptoms, most common being headache followed by fever, vomiting and neck stiffness. Biochemical parameters did not significantly contribute to diagnosis.

KEYWORDS: Cryptococcus neoformans; meningitis; Latex agglutination test; CD4cell count.

INTRODUCTION: Human immunodeficiency virus (HIV) infection has emerged as the fifth leading cause of death infecting approximately 40.3 million people worldwide, since the first reported case in the early 1980 s. $^{1}$

Cryptococccosis is the second most common fungal infection after candidiasis in HIV infected individuals and potentially the most serious infection. ${ }^{2}$ CNS infection is by far the most frequent manifestation of the cryptococcosis and is a potentially serious condition. Once considered as 'sleeping disease' has turned out to be an awakening giant within few years. It has been presumed to be 'mycosis of the future'. ${ }^{3}$ Classical meningeal symptoms occur in only about a quarter or one third of the patients, which causes a delay in the diagnosis. ${ }^{4}$

Often CD4 count is used as surrogate marker to screen these patients with CNS symptoms for the possible etiological role of Cryptococcus neoformans. Prevalence of Cryptococcal meningitis is inversely proportional to the CD4 cell count. ${ }^{1}$

At present CD4 count $<50$ is regarded to be increasingly associated with Cryptococcal meningitis.1, 5 With this background the present prospective study was under taken to analyze and compare the demographic, laboratory and CD4 level between the cryptococcal meningitis and other causes of meningitis in HIV seropositive individuals.

MATERIALS AND METHODS: A total of 106 consecutive CSF samples from HIV seropositive patients with suspected meningitis cases admitted a tertiary care hospital, India constituted the study 
material. All the samples were subjected to routine cytological and biochemical analysis, further processed for bacterial and fungal culture as per standard protocol6. The CSF Samples were centrifuged at $1500 \mathrm{rpm}$ for 15 minutes and the centrifuged sediment collected by aseptic technique. Supernatant was used for Latex Agglutination Test (LAT) using Latex Cryptococcus antigen detection system by Immuno-Mycologics Inc. (IMMY, U.S.A.) CD4 count was estimated by flow cytometry using BD FACS Calibur system. Data generated was analyzed using SPSS 17 software.

RESULTS AND OBSERVATION: The incidence of Cryptococcal meningitis was found to be $27.36 \%$ in our study as detected by Latex agglutination test. At all age groups the expected and observed number is same among males with Cryptococcal meningitis. Among females with Cryptococcal meningitis there is almost double the number of cases than expected in the 31-40 year age group. Occurrence of Cryptococcal meningitis in males of all age groups is equally distributed but in females there is increased prevalence in 31-40 year group. Majority of the patients with Cryptococcal meningitis were in 31-40 year age group. (Observed value is much higher than expected).

Males constituted 58.5\% among the study group. In patients with Cryptococcal meningitis males accounted for $65.5 \%$.

Patients presented with wide array of symptoms, most common being headache followed by fever, vomiting, neck stiffness, abnormal behavior, seizures and altered sensorium. CD4 count was ranging from 8 to 380 cells/ $\mu$ l (83.90 78.81$)$.Distribution of CD4 count among Cryptococcal meningitis patients is presented in Table 1 . Majority 22(75.86\%) had count $<100$ cells/ $\mu$ l. Only three $(10.34 \%)$ patients had CD4 count $>200$ cells $/ \mu$ l.

Biochemical analysis of CSF revealed glucose, protein \& chloride levels within normal range in majority of patients. Of these 13/29(44.82\%) had decreased CSF glucose level $(<40 \mathrm{mg} / \mathrm{dl})$, $17 / 29(58.62 \%)$ had increased protein level (> 40mg/dl) \& 11/29 (37.93\%) had increased chloride level (>110 mmol/L).On CSF cytoanalysis lymphocytes were observed in some of the samples ranging from $10-50$ cells $/ \mu$ l.

Out of 106 HIV seropositive patients with suspected features of meningitis, 29 had Cryptococcal meningitis, 15 had Tubercular meningitis, one had Toxoplasmosis and remaining samples were negative for bacterial and fungal culture.

Patients were treated with amphotericin B $0.7-1 \mathrm{mg} / \mathrm{kg} /$ day and fluconazole $400-800 \mathrm{mg} /$ day for 10-12 weeks followed by $200-400 \mathrm{mg} /$ day maintenance dose. Majority $21(80.76 \%)$ of the cases responded well. Three of them took discharge against medical advice and lost for follow up. Five (17.24\%) patients expired within 96hours of hospitalization.

DISCUSSION: The incidence of Cryptococcal meningitis among HIV infected cases in our study was $27.36 \%$ which is in near agreement with other reports viz. Peter RK et al[6] 27\%, Khyriem AB et al ${ }^{7}$ $26 \%$, slightly lower than as reported by Manoharan G et al $34.8 \%{ }^{8}$

The age range at presentation was 20 to 55 years, with overall mean age 35.37 years. Females (mean age 34 years) presenting slightly earlier than males (mean age 36.84 years). Highest incidence of Cryptococcal meningitis was in the age group of 31-40 year (62.06\%). There is an apparent increase in the incidence among males (by 7\%) as compared to that in the study group.

This increase is statistically not significant but rather due to chance. Although more men are reported to develop Cryptococcal disease, the male to female ratio is essentially 1:1, when adjusted 
for the male predominance in HIV infection. Cryptococcosis in children in AIDS is less common with the prevalence of approximately $1.4 \% .{ }^{9}$

These findings are similar to the findings of other studies viz.

In a study conducted by Lakshmi et al $(n=39)$, prevalence of CNS cryptococcosis seen in males was $84.62 \%$ and females $15.38 \%$. Mean age of affected was 31 years. Highest incidence was among 20 to 40 year old $(92.31 \%){ }^{1}$

In a study conducted by Iyer RS et al patients presenting with cryptococcal meningitis in the backdrop of HIV infection were in the age group of 35 to55 years. ${ }^{4}$

In a study done by Manoharan et al, observed that the highest incidence was in the age group of 30 to 40 years (51.6\%) and males were predominantly affected (93.5\%). ${ }^{8}$

In a study conducted by Liu $\mathrm{Z}$ et al $(\mathrm{n}=26)$ mean age of Cryptococcal meningitis was 35.6 years. ${ }^{10}$

The clinical presentations were varied, the most common symptoms being headache (68.96\%), followed by fever (58.62\%), vomiting (51.72\%), neck stiffness (37.93\%), abnormal behavior (13.79\%), seizures $(6.89 \%)$ and altered sensorium $(3.44 \%)$. None of them exhibited skin manifestations.This is in tune with the other studies viz.

\begin{tabular}{|c|c|c|c|c|c|}
\hline Symptoms & $\begin{array}{c}\text { Our study } \\
n=29\end{array}$ & $\begin{array}{r}\text { Chuck } \\
\text { et al }{ }^{3} \\
n=106\end{array}$ & $\begin{array}{c}\text { Kapila } \\
\text { et al }{ }^{3} \\
n=7\end{array}$ & $\begin{array}{c}\text { Satishchandra } \\
\text { et } \mathbf{a l}^{3} \\
\mathbf{n}=37\end{array}$ & $\begin{array}{c}\text { Lakshmi } \\
\text { et al1 } \\
n=39\end{array}$ \\
\hline headache & $68.96 \%$ & $73 \%$ & $85.7 \%$ & $97.3 \%$ & $92.31 \%$ \\
\hline fever & $58.62 \%$ & $45 \%$ & $42.8 \%$ & $86.5 \%$ & $79.49 \%$ \\
\hline vomiting & $51.72 \%$ & $42 \%$ & $42.8 \%$ & $51.3 \%$ & $51.28 \%$ \\
\hline neck stiffness & $37.93 \%$ & $22 \%$ & $14.2 \%$ & - & $66.67 \%$ \\
\hline abnormal behavior & $13.79 \%$ & $17 \%$ & $42.8 \%$ & - & $2.56 \%$ \\
\hline altered sensorium & $3.44 \%$ & $28 \%$ & $28.5 \%$ & $75 \%$ & $71.79 \%$ \\
\hline
\end{tabular}

In a study conducted by George JM et al $(n=12), 5.9 \%$ of patients with Cryptococcus infections and AIDS had skin lesions. ${ }^{11}$ Cutaneous infection is observed in $15 \%$ of patients with disseminated Cryptococcosis in AIDS. ${ }^{12}$

At present Cryptococcal meningitis is considered as rare before CD 4 cell count falls below 50 cells/ml. Graybill et al have reported the mean CD4 count for the four groups studied range between 18-21cells/ml 13. In our study mean CD4count of patients with confirmed cryptococcosis was 77.759. No doubt, there was increased incidence (38.7\%) of Cryptococcal meningitis in patients with CD4count $<51$, incidence among patients with different CD4 count ranges i.e. 51-100, 101- 200, 201400 were also above $17.4 \%$. Even in those with CD4 count 201-400 the incidence was $25 \%$ as detected by LAT. Among the patients with CD4 count $<50,38.7 \%$ were positive by LAT. Whereas among patients with CD4 count $>100,20 \%$ were positive by LAT. LAT could detect more cases even in those with higher CD4 count range.

It was observed that CSF glucose was never above normal range; CSF protein and chloride were never below normal range in these patients. The persistence of low glucose level is considered a poor prognostic finding. ${ }^{14}$ In our study $13(44.82 \%)$ patients had decreased CSF glucose level. 
CSF cytological analysis revealed predominant lymphocytes. Their number varied widely indicating no conclusive change in cell cytology. There may be little if any change in the findings of cytology and biochemistry of the CSF of Cryptococcal meningitis patients ${ }^{3}$.

Cryptococcal meningitis to be suspected in all cases with CNS manifestations among HIV seropositive patients as the clinical picture varies broadly. It was estimated that cryptococcosis decrease the survival rate of AIDS patient by 2 years regardless of CD4 count in the pre HAART era. Current trends have changed due to marked improvement of quality \& length of life produced by highly active antiretroviral therapy (HAART) \& potent antifungal agents. The need of the hour for diagnosis of Cryptococcal meningitis is of a test that is rapid, highly specific and sensitive.

Culture though the most reliable, as the isolation of organism from body fluids is regarded as the gold standard from time immemorial, takes 2-7 days for the growth to appear whereas result of antigen detection by LAT is available within 30 minutes. India ink preparation though rapid \& economical falls short of sensitivity.

The advantages of LAT seem to outweigh its cost factor. Considerable proportion of mortality can be evaded through proper timely diagnosis \& appropriate therapy.

CONCLUSION: The incidence of Cryptococcal meningitis was found to be $27.36 \%$ in our study. Cryptococcal meningitis patients presented with wide array of symptoms, most common being headache followed by fever, vomiting and neck stiffness. Biochemical parameters did not significantly contribute to diagnosis. Most of the patients (75.85\%) with cryptococcal meningitis had severely depleted CD4 count $(<100$ cells $/ \mu \mathrm{l})$.

\section{REFERENCES:}

1. Lakshmi V, Sudha T, Teja VD, Umabala P. Prevalence of central nervous system cryptococcosis in Human Immunodeficiency virus reactive hospitalised patients. Indian J. Med Microbiol 2007; 146-149

2. Jagdish chander. Text book of Medical Mycology, chapter 22, 2ndEd, Mehta publishers; 2002:231-249.

3. Kapila K, Sharma YV, Kotwal J, Bannerjee A, Kaur J. Cryptococcal meningitis: A clinicopathological account of seven cases encountered in a military setting. MJAFI 2003; 59:189-93.

4. Iyer RS, Banker DD. Cryptococcal meningitis in AIDS. Indian J. Med Sci 2002; 56:593-97.

5. Braunwald, Fauci, Kasper, Hanser, Longo, Jameson in Harrison's principles of internal medicine. Volume I, 17th edition, chapter 195, Mc Graw Hill; 2008:1251-53.

6. Betty A. Forbes, Daniel F. Salim, Alice S. Weissfeld. Bailey and Scott's Diagnostic Microbiology, $12^{\text {th }}$ edition, Mosby: 2007; 711-788.

7. Khyriem AB, Sujatha S, Das AK, Parija SC. Comparison of latex agglutination and coagglutination for the diagnosis and prognosis of cryptococcal meningitis. Indian J. Med Microbiol 2003; 21:252-56.

8. Manoharan G, Padmavathy BK, Vasanthi S, Gopalte R. Cryptococcal meningitis among HIV infected patients. Indian J Med Microbiol 2001; 19:157-58.

9. Abadi J, Nachman S, Kressel A B, Pirofski L. Cryptococcosis in children with AIDS. Clin Infect Dis 1999; 28:309-13. 
10. Liu Z, Wang A, Li T, Qin S, Sheng R. A clinical study of 26 cases of Cryptococcal meningitis. Zhonghua Nei Ke Za Zhi. 2002; 41(8):541-3.

11. Murakawa GJ, Kerschmann R, Berger T. Cutaneous Cryptococcus infection and AIDS. Arch Dermatol 1996; 132:545-548.

12. Elias J. Anaissie, Michael R McGinnis, Michael A. Pfaller. Chapter 9, Clinical Mycology, $1^{\text {st }}$ Ed, Churchill Livingstone; 2003:240-58.

13. Graybill J.R, J.Sobel. The role of lumbar puncture in the management of elevated intracranial pressure in patients with AIDS associated Cryptococcal meningitis. Clinical Infect Dis.2000; 31:1310-1.

14. Diamond R.D, J.E. Bennett. Prognostic factors in Cryptococcal meningitis-A study in 111 cases.Ann.Intern.Med.1974; 80:176-81.

\begin{tabular}{|l|c|c|c|c|c|c|}
\hline \multirow{2}{*}{ Age in years } & \multicolumn{2}{|c|}{ Male } & \multicolumn{2}{c|}{ Female } & \multicolumn{2}{c|}{ All cases } \\
\cline { 2 - 7 } & No & $\mathbf{\%}$ & No & \% & No & \% \\
\hline Up to 20 & 3 & 4.8 & 5 & 11.4 & 8 & 7.5 \\
\hline $21-30$ & 10 & 16.1 & 15 & 34.1 & 25 & 23.6 \\
\hline $31-40$ & 33 & 53.2 & 17 & 38.6 & 50 & 47.2 \\
\hline $41-50$ & 12 & 19.4 & 4 & 9.1 & 16 & 15.1 \\
\hline$>50$ & 4 & 6.5 & 3 & 6.8 & 7 & 6.6 \\
\hline Total & $\mathbf{6 2}$ & $\mathbf{1 0 0 . 0}$ & $\mathbf{4 4}$ & $\mathbf{1 0 0 . 0}$ & $\mathbf{1 0 6}$ & $\mathbf{1 0 0 . 0}$ \\
\hline Mean \pm SD & \multicolumn{2}{|c|}{$\mathbf{3 6 . 8 4} \pm \mathbf{8 . 8 5}$} & $\mathbf{3 3 . 2 3} \pm \mathbf{1 1 . 3 5}$ & $\mathbf{3 5 . 3 4} \pm \mathbf{1 0 . 0 7}$ \\
\hline
\end{tabular}

Table I: Age distribution of study patients according to gender

\begin{tabular}{|c|c|c|c|c|c|c|c|c|c|}
\hline \multirow{2}{*}{$\begin{array}{c}\text { Age in } \\
\text { years }\end{array}$} & \multicolumn{4}{|c|}{ Male } & \multicolumn{3}{c|}{ Female } & \multicolumn{3}{c|}{ All cases } \\
\cline { 2 - 11 } & $\begin{array}{c}\text { Expected } \\
\text { No. }\end{array}$ & $\begin{array}{c}\text { Observed } \\
\text { no. }\end{array}$ & $\%$ & $\begin{array}{c}\text { Expected } \\
\text { no. }\end{array}$ & $\begin{array}{c}\text { Observed } \\
\text { no. }\end{array}$ & $\begin{array}{c}\text { Expected } \\
\text { no. }\end{array}$ & $\begin{array}{c}\text { Observed } \\
\text { no. }\end{array}$ & $\%$ \\
\hline Upto 20 & 00.00 & 0 & 00.00 & 01.14 & 1 & 10 & 02.17 & 1 & 03.40 \\
\hline $21-30$ & 03.99 & 4 & 21.05 & 03.41 & 1 & 10 & 06.84 & 5 & 17.24 \\
\hline $31-40$ & 09.99 & 10 & 52.60 & 03.86 & 8 & 80 & 13.66 & 18 & 62.06 \\
\hline $41-50$ & 03.99 & 4 & 21.05 & 00.90 & 0 & 00 & 04.37 & 4 & 13.79 \\
\hline$>50$ & 00.99 & 1 & 05.26 & 00.68 & 0 & 00 & 01.90 & 1 & 03.40 \\
\hline Total & $\mathbf{1 9}$ & $\mathbf{1 9}$ & $\mathbf{1 0 0}$ & $\mathbf{1 0}$ & $\mathbf{1 0}$ & $\mathbf{1 0 0}$ & $\mathbf{2 9}$ & $\mathbf{2 9}$ & $\mathbf{1 0 0}$ \\
\hline Mean & \multicolumn{3}{|c|}{$\mathbf{3 6 . 1 0}$} & \multicolumn{7}{|c|}{$\mathbf{3 4 . 0 0}$} & & \multicolumn{3}{c|}{$\mathbf{3 5 . 3 7}$} & \\
\hline
\end{tabular}




\begin{tabular}{|l|c|c|c|c|}
\hline \multirow{2}{*}{ Gender } & \multicolumn{2}{|c|}{ Over all } & \multicolumn{2}{c|}{$\begin{array}{c}\text { Cryptococcal } \\
\text { meningitis }\end{array}$} \\
\cline { 2 - 5 } & No & \% & No & \% \\
\hline Male & 62 & 58.5 & 19 & 65.5 \\
\hline Female & 44 & 41.5 & 10 & 34.5 \\
\hline \multicolumn{1}{|c|}{ Total } & $\mathbf{1 0 6}$ & $\mathbf{1 0 0 . 0}$ & $\mathbf{2 9}$ & $\mathbf{1 0 0 . 0}$ \\
\hline
\end{tabular}

Table III: Gender distribution of patients with Cryptococcal meningitis in comparison with overall ratio in patients under study

\begin{tabular}{|l|c|c|c|c|}
\hline Symptoms & $\begin{array}{c}\text { Study } \\
\text { group (n=106) }\end{array}$ & Percentage & $\begin{array}{c}\text { Cryptococcal } \\
\text { meningitis group (n=29) }\end{array}$ & Percentage \\
\hline 1. Fever & 75 & 70.8 & 17 & 58.62 \\
\hline 2. Headache & 64 & 60.4 & 20 & 68.96 \\
\hline 3. Seizures & 37 & 34.9 & 02 & 06.89 \\
\hline 4. Vomiting & 36 & 33.9 & 15 & 51.72 \\
\hline 5. Neck stiffness & 26 & 24.5 & 11 & 37.93 \\
\hline 6. Altered sensorium & 16 & 15.1 & 01 & 03.44 \\
\hline 7. Abnormal behavior & 14 & 13.2 & 04 & 14.79 \\
\hline 8. Weakness of limbs & 1 & 0.9 & 00 & 00.10 \\
\hline
\end{tabular}

Table IV: Symptoms of among study group and Cryptococcal meningitis patients

\begin{tabular}{|l|c|c|c|c|}
\hline CD4 COUNT & $\begin{array}{c}\text { No. of patients } \\
\text { Under } \\
\text { study group }\end{array}$ & \% distribution & $\begin{array}{c}\text { No. Of } \\
\text { Cryptococcal } \\
\text { meningitis patients }\end{array}$ & \% distribution \\
\hline$<51$ & 31 & 29.2 & 12 & 41.37 \\
\hline $51-100$ & 40 & 37.7 & 10 & 34.48 \\
\hline $101-200$ & 23 & 21.7 & 4 & 13.79 \\
\hline $201-500$ & 12 & 11.3 & 3 & 10.37 \\
\hline Total & $\mathbf{1 0 6}$ & $\mathbf{1 0 0}$ & $\mathbf{2 9}$ & $\mathbf{1 0 0}$ \\
\hline \multicolumn{5}{|c|}{ Table V: Distribution of CD4 count among study } \\
group and Cryptococcal meningitis patients \\
\hline
\end{tabular}

\begin{tabular}{|l|c|c|c|c|}
\hline Parameters & $\begin{array}{c}\text { Study } \\
\text { group }\end{array}$ & $\begin{array}{c}\text { Number of } \\
\text { Cryptococcal meningitis } \\
\text { patients }\end{array}$ & $\mathbf{\%}$ & $\begin{array}{c}\mathbf{P} \\
\text { value }\end{array}$ \\
\hline \multicolumn{7}{|l|}{ Immunological parameters (CD4 counts) } \\
\hline$<51$ & 31 & 12 & 38.7 & 0.1584 \\
\hline $51-100$ & 40 & 10 & 25.0 & 0.7336 \\
\hline $101-200$ & 23 & 4 & 17.4 & 0.2823 \\
\hline $201-500$ & 12 & 3 & 25.0 & 0.8521 \\
\hline
\end{tabular}


ORIGINAL ARTICLE

\begin{tabular}{|c|c|c|c|c|}
\hline \multicolumn{5}{|c|}{ Biochemical parameters } \\
\hline \multicolumn{5}{|c|}{ Glucose } \\
\hline$<40$ & 42 & 13 & 30.9 & 0.6111 \\
\hline $40-60$ & 55 & 15 & 27.3 & 0.9867 \\
\hline$>60$ & 9 & 1 & 11.1 & 0.2729 \\
\hline \multicolumn{5}{|l|}{ Protein } \\
\hline$<20$ & 6 & 0 & 0.0 & - \\
\hline $20-40$ & 44 & 12 & 27.3 & 0.9886 \\
\hline$>40$ & 56 & 17 & 30.4 & 0.6147 \\
\hline \multicolumn{5}{|l|}{ Chloride } \\
\hline$<90$ & 7 & 2 & 28.6 & 0.9433 \\
\hline $90-110$ & 56 & 16 & 28.6 & 0.8404 \\
\hline$>110$ & 43 & 11 & 25.6 & 0.7913 \\
\hline Total & 106 & 29 & 27.4 & - \\
\hline
\end{tabular}

Normal range of CSF glucose $=40-60 \mathrm{mg} / \mathrm{dl}$

Normal range of CSF protein $=20-40 \mathrm{mg} / \mathrm{dl}$

Normal range of CSF chloride $=90-110 \mathrm{meq} / \mathrm{l}$

\section{AUTHORS:}

1. Madhusudhan N.S.

\section{PARTICULARS OF CONTRIBUTORS:}

1. Assistant Professor, Department of Microbiology, IGMC \& RI, Puducherry.

\section{NAME ADDRESS EMAIL ID OF THE} CORRESPONDING AUTHOR:

Dr. Madhusudhan N. S, No. 27, First Floor, $4^{\text {th }}$ Cross, Satyanagar, Saram, Puducherry - 605013.

E-mail: drnsmadhu98@gmail.com

Date of Submission: 12/02/2014. Date of Peer Review: 13/02/2014. Date of Acceptance: 21/02/2014. Date of Publishing: 11/03/2014. 